\title{
INOVASI PELAYANAN KELAHIRAN TERPADU DIRUMAH SAKIT UMUM DAERAH SUMBAWA
}

\author{
Kusmanto ${ }^{1^{\star}}$, Yossy Dwi Erliana ${ }^{2}$, Muhammad Hilmy Alfaruqi ${ }^{3}$ \\ ${ }^{1 *}$ Sekolah PascasarjanaUniversitasTeknologi Sumbawa \\ ${ }^{2}$ Fakultas Psikologi Universitas Teknologi Sumbawa \\ ${ }^{3}$ Fakultas Pascasarjana Universitas Teknologi Sumbawa \\ *Corresponding Author email:yossy.dwi.erliana@uts.ac.id, muhammad.hilmy.alfruqi@uts.ac.id
}

\begin{tabular}{ll}
\hline & Abstrak \\
\cline { 2 - 3 } Diterima: & Pelayanan kelahiran terpadu merupakan inovasi dalam pembuatan administrasi \\
Bulan Januari & kependudukan di pelayanan kesehatan. pelayanan kelahiran terpadu memberikan \\
2021 & pelayanan pembuatan akte kelahiran, kartu identitas anak dan kartu keluarga dengan \\
& waktu penyelesaian pelayanan hanya 2 hari. Tujuan penelitian adalah untuk menganalisis \\
& implementasi kebijakan pelayanan kelahiran terpadu serta menganalisis fakor pendukung \\
Diterbitkan: & dan penghambat dalam inovasi pelayanan kelahiran terpadu. Jenis penelitian ini \\
Bulan Februari & deskriptif dengan pendekatan Cross Sectional, dengan fokus penelitian membentuk \\
2021 & standar prosedur opersional dalam inovasi pelayanan kelahiran yang terpadu untuk \\
& penerbitan akte kelahiran, kartu identitas anak dan perubahan kartu keluarga bagi pasien \\
Keyword: & yang melahirkan dirumah sakit umum daerah Sumbawa, . Hasil penelitian menunjukkan \\
Implementasi dan & bahwa pelayanan kelahiran terpadu merupakan pelayanan yang efisien dan efektif hal ini \\
Kebijakan & dapat dilihat dari segi inovasi proses layanan yang mudah dan inovasi metode layanan \\
& yang cepat karena setiap pasien yang diperbolehkan pulang akan langsung mendapatkan \\
& kartu keluarga baru, akte kelahiran anak dan kartu identitas anak secara gratis.
\end{tabular}

\section{PENDAHULUAN}

Salah satu amanat Undang - Undang Dasar yaitu memberikan pelayanan dan perlindungan terhadap seluruh warganya. Hal ini mengindikasikan bahwa pemerintah harus berpihak kepada masyarakat, memahami keberpihakan ini sebagai tuntutan mendekatkan pemerintah dengan masyarakat, sehingga pemerintah dapat memberikan respon secara cepat terhadap kebutuhan masyarakat yang dinamis. Pelayanan publik yang bertujuan memberikan pelayanan kepada warga negara, harus memiliki konsep pelayanan yang mencakup seluruh aspek kehidupan warga negara. Negara bagi masyarakat dijadikan tumpuan untuk mendapatkan hak-hak dan jaminan atas kelangsungan hidup masyarakat yang sesuai dengan Undang-Undang Dasar 1945. Pemerintah berkewajiban menyelenggarakan pelayanan publik yang berkualitas bagi warganya.

Dalam pembangunan bangsa Indonesia Pelayanan publik kini telah menjadi isu yang sentral. Sebagian masyarakat sering kali mendapatkan pengabaian atau pelayanan yang seadanya, pelayanan publik sering kali dianggap hanya sekedar menggugurkan kewajiban dan sebagai bagian dari tugas rutin semata. Pelayanan publik yang diselenggarakan harus dapat memberikan rasa keadilan bagi seluruh lapisan masyarakat sesuai dengan sila kelima pancasila yang menjadi dasar negara Indonesia.
Tingkat kepatuhan pemerintah dalam memenuhi standar pelayanan publik masih rendah baik di tingkat pemerintah pusat maupun pemerintah daerah. Kepatuhan dalam menerapkan standar pelayanan publik sesuai Undang - Undang nomor 25 tahun 2009 tentang pelayanan publik belum maksimal diterapakan. Laporan terbaru Ombudsman RI (http://tirto.id rapor merah pelayanan publik di Indonesia, diakses 20 Januari pukul 16.00) terkait. Tiga masalah penting yang banyak terjadi dalam terselenggaranya pelayanan publik, yaitu pertama adalah masih banyaknya diskriminasi pelayanan. Undang-Undang No.28 Tahun 1999 tentang Penyelenggaraan Negara yang bersih dari KKN merupakan salah satu cara menghilangkan diskriminasi dalam pelayanan yang sering dipengaruhi oleh faktor kekerabatan, hubungan kesamaan afiliasi politik, etnis, dan agama. Kedua, tidak adanya kepastian biaya dan waktu pelayanan. Untuk mendapatkan kepastian dan kemudahan dalam pelayanan, masyarakat sebagai pengguna jasa pelayanan cenderung membayar dengan biaya lebih sehingga membuka peluang untuk praktek korupsi, kolusi dan nepotisme dalam memberikan pelayanan. Ketiga, rendahnya tingkat kepuasan masyarakat terhadap pelayanan publik (Dwiyanto, 2015 : 102 dalam jurnnal administrasi publik oleh Rokhman, dkk. 2016).

Pemerintah daerah telah diberikan kebebasan untuk mengatur potensi- potensi sumber dayanya demi kemajuan birokrasi dan kepuasan masyarakat. 
Pemerintah daerah memiliki hak otonom untuk mengatur sendiri urusan pemerintahan dan memberikan pelayanan publik terhadap kepentingan warganya, sesuai dengan amanat Undang - Undang no. 32 tahun 2004. Pelayanan publik harus terus di perbaiki tentunya dengan tetap memperhatikan peraturan yang ada. Salah satu pelayanan publik yang menjadi kebutuhan warga negara yaitu tentang identitas kependudukan atau administrasi kependudukan. Peraturan pemerintah yang mengatur penyelenggaraan keweangan urusan administrasi kependuduakan dipemerintahan pusat dan pemerintah daerah. Undang-Undang no. 24 tahun 2013 merupakan serangkaian kegiatan penerbitan dokumen dan data kependudukan untuk memenuhi kebutuhan masyarakat dibidang pelayanan administrasi kependudukan.

Berbagai bentuk pelayanan administrasi kependudukan adalah penerbitan Kartu Keluarga (KK), Kartu Tanda Penduduk (KTP) dan Akte Kelahiran. Negara menjamin keberadaan warganya dan hak hak sipil lainnya berdasarkan data penerbitan identitas kependudukan bagi warganya. Pelayanan seperti ini sangat penting dan menjadi bagian dari pelayanan publik yang harus di selenggarakan oleh Negara (Patmasari, 2016). Identitas sebagai warga negara dibuktikan dengan kepemilikan akte kelahiran, dalam pelayanan penerbitan akte kelahiran masih harus terus diperbaiki. Setiap anak berhak atas suatu nama dan status kewarganegaraan sejak dilahirkan yang di tuangkan dalam akte kelahiran, pemerintah telah menjelaskan dalam Undang-Undang no. 23 tahun 2002 terkait perlindungan anak. Salah satu penyebab tingginya angka kasus perdangan anak, pemalsuan identitas, mempekerjakan anak dibawah umur dan kasus sosial lainnya, karena banyaknya anak yang tidak memiliki identitas kependudukan.

Kebutuhan kejelasan status bagi warga negara saat ini masih belum mejadi kebutuhan primer. Kondisi ini merupakan tantangan yang membutuhkan langkah perubahan sistem serta mekanisme kerja pemerintah dalam meningkatkan pemahaman bagi warganya dalam memenuhi kebutuhan rutin pencatatan status sipilnya berupa tertib pelaporan hal-hal yang dialami, seperti halnya peristiwa lahir, mati, pindah dan datang. Terdapat sejumlah manfaat dari kepemilikan akta kelahiran, yaitu (www.dispendukcapil.sumbawakab.go.id diakses 22/01/2020 pukul 09.00 WIB) menjadi bukti bahwa negara mengakui atas identitas seseorang yang menjadi warganya, yakni (1) Sebagai alat dan data dasar bagi pemerintah untuk menyusun anggaran nasional dalam bidang pendidikan, kesehatan, sosial dan perlindungan anak, (2) Merupakan bukti awal kewarganegaraan dan identitas diri pertama yang dimiliki anak, (3) (3) Menjadi bukti kuat bagi anak untuk mendapatkan hak waris dari orang tua, (4) Mencegah pemalsuan umur dan perkawinan di bawah umur, (5) Secara yuridis anak berhak untuk mendapatkan perlindungan, kesehatan, pendidikan, pemukiman dan hak-hak lain sebagai warga negara.

Pengurusan akte kelahiran yang terlambat menjadi bukti masih rendahnya tingkat kesadaran masyarakat, dalam mengurus akte kelahiran. Keterlambatan mendaftarkan anak untuk mendapatkan akta kelahiran selain disebabkan oleh kurangnya kesadaran masyarakat, juga dipengaruhi ketidaklengkapan dokumen persyaratan pengajuan penerbitan akta kelahiran (hasil wawancara dengan kepala bidang pemanfaatan data dan inovasi pelayanan dispeduk capil kab. Sumbawa, 14 Januari 2020).

Keterlambatan mengurus akta kelahiran dapat disebabkan oleh beberapa masalah lain yang muncul, yaitu masyarakat kesusahan mengurus dari satu tempat ke tempat lain dan belum lagi waktu yang dibutuhkan untuk mengurus bisa seharian. Kesiapan diri untuk menyediakan waktu tersendiri dalam mengurus akte kelahiran juga menjadi penyebab terlambatnya pengurusan akte kelahiran selain dari permasalahan kelengkapan berkas dokumen. Hal ini diperkuat dengan pendapat salah satu masyarakat yang sedang mengurus surat keterangan lahir dirumah sakit umum daerah Sumbawa, yang mengatakan bahwa dalam mengurus akta kelahiran anaknya merasa kerepotan dalam mengatur waktu antara kantor dan ke Dispendukcapil. Prosedur pelaksanaan permohonan akta kelahiran di tahun 2009 sampai pertengahan 2016 masih mengharuskan pemohon datang sendiri ke Dinas Kependudukan dan Pencatatan Sipil atau Kantor Kecamatan setempat dengan membawa persyaratan sebagai berikut:

a. Mengisi formulir permohonan akta kelahiran;

b. Surat keterangan lahir dari desa/ kelurahan/ bidan/ puskesmas/ rumah sakit;

c. Fotocopy surat nikah yang dilegalisir oleh KUA/ asli ditunjukkan;

d. Fotocopy KK orang tua;

e. Fotocopy KTP 2 orang saksi (untuk E-KTP tunjukkan aslinya).

Dalam kasus ini dibutuhkan adanya suatu terobosan dan pembaharuan terhadap sistem pelayanan yang ada, sehingga kebijakan administrasi kependudukan di kabupaten Sumbawa sudah dicanangkan sejak tahun 2018 dengan menerbitkan Peraturan Bupati nomor 51 tahun 2019 yang merupakan perubahan atas Peraturan Bupati nomor 24 tahun 2018 tentang Percepatan Kepemilikan Akta Kelahiran Melalui Jalur Pendidikan, Kesehatan, Sistem Layanan Rujukan Terpadu dan Desa/kelurahan. Sistem ini merupakan bentuk Reformasi Birokrasi Pemerintah Kabupaten 
Sumbawa, agar pelayanan pembuatan akta kelahiran lebih mudah dan terjangkau oleh masyarakat. Dengan adanya Peraturan Bupati nomor 51 tahun 2019 rumah sakit umum daerah Sumbawa yang merupakan salah satu contoh pelayanan publik harus membuat inovasi sebagai solusi dari fenomena di atas yaitu dengan menerapkan inovasi sistem pelayanan kelahiran terpadu. Dengan terbentuknya Sistem kerja atau standar prosedur operasional antara pelayanan kesehatan khususnya rumah sakit umum daerah sumbawa dengan dinas kependudukan dan catatan sipil, maka pelayanan penerbitan akta kelahiran, perubahan kartu kelurga dan penerbitan kartu identitas anak bagi bayi baru lahir secara cepat dan gratis. Konsep ini merupakan konsep percepatan pelayanan penerbitan akta kelahiran, kartu keluarga dan kartu identitas anak yang pertama kali dilaksanakan di kabupaten Sumbawa demi menunjang peningkatan kualitas pelayanan publik. Sasaran dalam pelayanan ini adalah semua lapisan masyarakat Sumbawa yang melahirkan di rumah sakit umum daerah Sumbawa syarat bayi masih berumur 0-2 hari.

"keuntungan lain selain mengurus akta kelahiran dengan waktu dan biaya yang sedikit adalah melalui program ini masyarakat tidak perlu dua kali jalan untuk mengurus kartu keluarga baru lagi" (wawancara dengan Bapak Andi Rahman, Kepala Bidang Pemanfaatan Data dan Inovasi Pelayanan Dinas Kependudukan dan Pencatatan Sipil, 14 Januari 2020)

Peneliti memilih tempat penelitian dengan keadaan administrasi yang baik tetapi belum memaksimalkan regulasi sistem administrasi kependudukan yang sesuai dengan Peraturan Bupati nomor 51 tahun 2019 karena setiap bayi yang dilahirkan di rumah sakit umum daerah Sumbawa hanya dibekali dengan surat keterangan lahir pada saat pasien sudah di perbolehkan keluar rumah sakit dan $90 \%$ dari pasien datang mengurus surat keterangan lahir lagi setelah dengan berbagai alasan diantaranya surat keterangan hilang, baru ada kesempatan mengurus dan sebagainya. maka dari itu peneliti memilih RSUD Sumbawa sebagai tempat pertama kali program dilaksanakan.

\section{LANDASAN TEORI}

\section{Pelayanan publik}

Alkano (2016) pelayanan publik dapat diartikan sebagai pemberian layanan (melayani) keperluan kepada seseorang atau masyarakat yang mempunyai kepentingan pada organisasi itu sesuai dengan aturan dan tata cara yang telah ditetapkan.

Pelayanan publik menurut Undang-Undang Republik Indonesia Nomor 25 tahun 2009 pasal I ayat (1) bahwa pelayanan publik adalah kegiatan atau rangkaian kegiatan dalam rangka pemenuhan kebutuhan pelayanan sesuai dengan peraturan perundang-undangan dan setiap warga negara dan penduduk atas barang, jasa dan atau pelayanan administratif yang disediakan oleh penyelenggara pelayanan publik.

Sedangkan menurut Keputusan Mentri Pendayagunaan Aparatur Negara Nomor 25 Tahun 2004 definisi pelayanan publik adalah segala kegiatan pelayanan yang dilaksanakan oleh penyelenggara pelayanan publik sebagai upaya pemenuhan kebutuhan penerima layanan, maupun dalam rangka pelaksanaan ketentuan peraturan perundang undangan. Jenis pelayanan tersebut dapat didasarkan pada ciri-ciri dan sifat kegiatan serta produk pelayanan yang dihasilkan, yaitu pelayanan administratif, pelayanan barang dan pelayanan jasa.

\section{Langkah-langkah meningkatkan kualitas layanan}

Idealnya kualitas layanan yang diterima konsumen sama dengan kualitas layanan yang mereka harapkan. Ketika kualitas layanan yang di berikan tidak sesuai dengan kualitas layanan yang diharapkan konsumen, maka akan muncul kesenjangan (gap). Oleh karena itu agar konsumen puas terhadap kualitas layanan yang diberikan perusahan, maka menjadi keharusan bagi perusahaan untuk menghilangkan gap yang terjadi. Namun jika upaya menghilangkan gap sulit dilakukan, paling tidak perusahan harus berupaya mengurangi gap semenimal mungkin.

Barata (2015) memberikan kerangka komprehensif dan runtut untuk menghilangkan gap 1 hingga gap 4. Terdapat empat langkah untuk menghilangkan gap kualitas layanan, yaitu : (1) Menumbuhkan kepemimpinan yang efektif, Kepemimpinan merupakan penggerak utama perbaikan layanan. Tanpa layanan yang epektif, kepemimpinan tanpa visi dan arah yang jelas, serta tanpa bimbingan manajemen puncak, upaya perbaikan layanan yang berkualitas tidak bisa diciptakan. Untuk mengembangkan kepemimpinan yang epektif, empat cara berikut bisa ditempuh, yaitu : mendorong kelancaran proses pembelajaran di kalangan top manajemen, promosi orang yang tepat pada jabatan eksekutif puncak, mendorong peran individu, mengembangkan budaya saling percaya. (2) Membangun sistem informasi layanan, Sistem pelayanan informasi yang epektif akan mengakomodasikan keinginan dan harapan konsumen, mengidentifikasi kekurangan yang diberikanperusahaan, memandu alokasi sumber daya perusahaan untuk peningkatan kualitas layanan dan memungkinkan perusahaan memantau layanan pesaing. (3) Merumuskan inovasi layanan, strategi layanan adalah strategi untuk memberikan layanan dengan kualitas sebaik mungkin kepada konsumen. strategi layanan harus menjadi pedoman bagi pekerja sehingga pelaksanaan pekerjaan harus 
mengacu pada tujuan yang ditetapkan. (4) Implementasi strategi layanan,. strategi layanan dapat di implementasikan dengan efektif jika syaratsyarat berikut ini dipenuhi : struktur organisasi yang memungkinkan berkembangnya budaya perusahaan dengan titik berat pada perbaikan berkelanjutan, menjadi pedoman bagi perbaikan kualitas layanan, peningkatan kemampuan teknis sumber daya yang mendukung perbaikan kualitas layanan, serta memberikan solusi terhadap setiap persoalan yang menyangkut kualitas layanan, teknologi yang applicable untuk memperbaiki sumber daya, metode kerja dan sistem informasi yang mendukung upaya perbaikan kualitas layanan, sumber daya mausia yang memiliki sikap, perilaku, pengetahuan dan pengetahuan yang mendukung efektivitas realisasi strategi layanan.

\section{Pelayanan Terpadu}

Merupakan kegiatan penyelenggaraan suatu perizinan atau nonperizinan yang mendapat pendelegasian wewenang dari instansi yang memiliki kewenangan yang proses pengelolaannya dimulai dari tahap permohonan sampai dengan tahap terbitnya dokumen yang diperlukan (Keputusan Mentri Pendayagunaan Aparatur Negara, 2004). Pelayanan terpadu satu pintu (PTSP) bukanlah kebijakan baru didalam manajemen birokrasi. Pembentukan PSTP di daerah termasuk dalam rangka mendekatkan dan meningkatkan pelayanan kepada masyarakat serta memperpendek pelayanan guna mewujudkan pelayanan yang cepat, mudah, murah, transparan, kepastian dan terjangkau. Praktek pelayanan terpadu saat ini menggunakan dasar hukum : (1) Perat uran Presiden Nomor 97 tahun 2014 dibawah kendali Badan Koordinasi Penanaman Modal (BPKPM) (2) Keputusan Menteri Dalam Negeri Nomor 24 tahun 2006 tentang Pedoman Pelayanan Terpadu Satu Pintu (3) Keputusan Menteri Pendayagunaan Aparatur Negara Nomor KEP/26/M.PAN/2/2004 tentang Petunjuk Teknis Transparansi dan Akuntabilitas dalam Penyelenggaraan Pelayanan Publik. (4) Keputusan Menteri Pendayagunaan Aparatur Negara Nomor 63/KEP/M.Pan/7/2003 tentang Pedoman Umum Penyelenggaraan Pelayanan Publik. Pelayanan Terpadu Satu Pintu memiliki kewenangan atas beberapa perizinan dan non perizinan, terdapat sekitar 25 bidang, sebagai berikut : linkungan Hidup, pendidikan, perumahan, peñataan ruang, pertanahan yang menjadi kewenagan daerah, kesehatan, pekerjaan umum, perindustrian, kehutanan, perlindungan Anak dan Pemberdayaan Perempuan, sosial, ketenagakerjaan dan transmigrasi, pertanian dan ketahanan pangan, komunikasi dan informasi, perpustakaan, olahraga dan pemudaan, kebudayaan dan pariwisata, koperasi dan UKM, penanaman modal, perdagangan, pembangunan, energy dan sumber daya mineral, perikanan dan kelautan, peternakan dan kesatuan Bangsa dan Politik Dalam Negeri

\section{Inovasi pelayanan kelahiran terpadu}

Kabupaten Sumbawa sudah memiliki landasan hukum administrasi kepemilikan akte kelahiran anak dengan diterbitkan peraturan bupati Sumbawa nomor 51 tahun 2019 sebagai perubahan atas peraturan bupati Sumbawa nomor 24 tahun 2018. Percepatan kepemilikan akta kelahiran melalui jalur kesehatan tertuang dalam peraturan bupati nomor 51 tahun 2019 mencakup tugas dan tanggung jawab rumah sakit dalam pengajuan penerbitan akta kelahiran anak. Tugas dan tanggung jawab rumah sakit umum daerah, yaitu : menerima berkas permohonan dari orang tua, menerbitkan Surat Keterangan Lahir, menyerahkan berkas permohonan kepada dinas, menerima akta kelahiran yang telah diproses dari dinas, menyerahkan akta kelahiran yang telah diterbitkan kepada orang tua.

Inovasi pelayanan ini di tujukan bagi pasien yang melahirkan di rumah sakit umum Sumbawa baik melahirkan melalui operasi Sectio Secaria (sc) maupun melahirkan secara spontan (normal).

Gambar : Alur Permohonan Akta Kelahiran

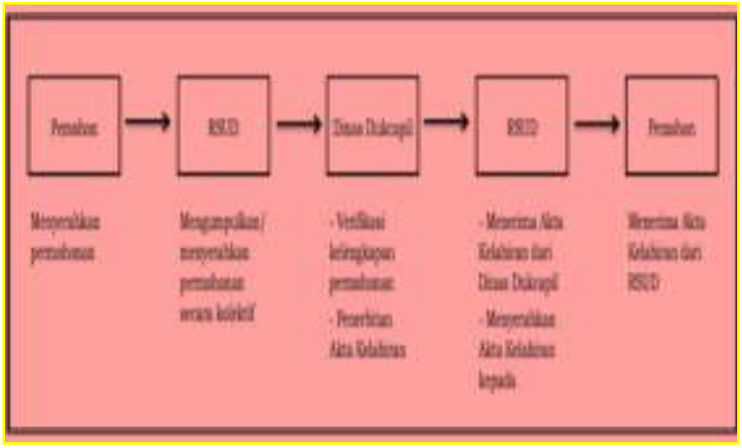

PERBUP Nomor 51 tahun 2019

Gambar : Alur inovasi pelayanan kelahiran terpadu di rumah sakit umum daerah Sumbawa

Adapun keunikan dan kebaruan dari inovasi ini terdiri dari : (1) Akta kelahiran diterbitkan dalam jangka waktu 1-2 hari setelah berkas diterima dan dinyatakan lengkap oleh dinas. (2) Pemohon akan mendapatkan juga perubahan kartu keluarga (KK) dan kartu identitas anak (KIA) dengan satu pengajuan. Adapun Manfaat bagi daerah dari inovasi ini dengan penerapan sistem pelayanan kelahiran terpadu yang bersinergi antara rumah sakit umum daerah Sumbawa dengan dinas kependudukan dan pencatatan sipil kabupaten Sumbawa akan meningkatkan tingkat kepatuhan masyarakat dalam melaksakan pencatatan setiap kelahiran anaknya, sehingga jumlah pertumbuhan penduduk setiap tahunnya akan di tercatat secara akurat dan pasti. 


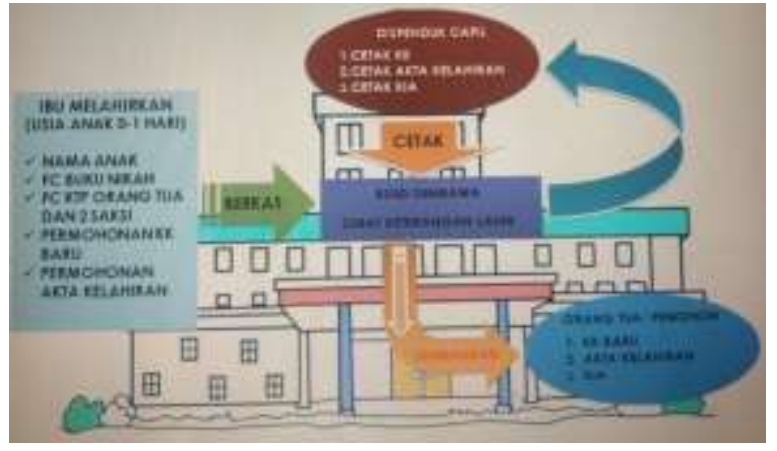

Gambar : Alur inovasi pelayanan kelahiran terpadu

1. Tahap Pertama : Setelah pasien mendapatkan penjelasan tentang inovasi kelahiran terpadu, maka pasien akan menyiapkan semua dokumen berkas kepada petugas rumah sakit, seperti : surat keterangan lahir dan nama anak, foto copy buku nikah, foto copy orang tua dan 2 orang saksi serta permohan pembuatan akte kelahiran dan kartu kluarga.

2. Tahap kedua :

a. Petugas dari rumah sakit akan mendatangi pasien untuk mengambil berkas dokumen kependudukan tersebut.

b. Selanjutnya berkas akan diverifikasi oleh petugas rumah sakit, apabila masih dinyatakan belum lengkap maka berkas akan langsung dikembalikan dan meminta pasien agar segera melengkapi kembali dokumen berkasnya.

3. Tahap Ketiga : Dokumen berkas yang sudah dinyatakan lengkap, selajutnya dibawa dan diserahkan ke dinas kependudukan dan catatan sipil untuk diverifikasi ulang kelengkapan berkasnya.

4. Tahap Keempat : Selanjutnya penerbitan dokumen kependudukan (akte kelahiran, kartu identitas anak, dan kartu keluarga) oleh dinas kependudukan dan catatan sipil.

5. Tahap Kelima : Dokumen kependudukan yang sudah diterbitkan akan di serahkan kembali ke petugas sumah sakit untuk selanjutnya di serahkan kepada pasien atau pemohon.

\section{LOKASI PENELITIAN}

Rumah sakit umum daerah Sumbawa (RSUD Sumbawa) merupakan rumah sakit milik Pemerintah Daerah Kabupaten Sumbawa Provinsi Nusa Tenggara Barat, berdiri sejak tahun 1950 pada awalnya terletak dikelurahan Brang Bara Sumbawa Besar. Pada tahun 1953 rumah sakit umum daerah Sumbawa mengtembangkan diri direlokasi ke jalan Garuda No. 5 Sumbawa Besar sampai dengan saat ini, luas tanah $8.120 \mathrm{~m}^{2}$ dan luas bangunan $6.876 \mathrm{~m}^{2}$ dengan klasifikasi rumah sakit type C. RSUD Sumbawa telah terakreditasi tingkat Madya sebgab sertifikat akreditasi nomor Komite Akreditasi Rumah Sakit (KARS) SERT/1012/I/2018 tanggal 10 januari 2018. Dalam memberikan pelayanan RSUD Sumbawa memiliki beberapa instalasi dan ruang rawat inap yaitu : Instalasi Rawat Darurat (IRD), Instalasi Rawat Jalan (IRJA), Instalasi Rawat Inap (IRNA), ruang bersalin (obgyn), Instalasi Bedah Sentral (IBS/OK), Instalasi Laboratorium, Instalasi Radiologi, Instalasi gizi, Instalasi Farmasi dan Instalasi Pemeliharaan Sarana (IPS). Peneliti melakukan penelitian di ruang bersalin (obgyn), Ruang obgyn mempunyai kapasitas 10 tempat tidur (ruang kelas 3 sebanyak 18 tempat tidur dalam 2 ruangan, kelas 2 sebanyak 5 tempat tidur dalam 2 ruangan dan kelas 1 sebanyak 2 tempat tidur dalam 2 ruangan). Jumlah perawat yang bekerja di ruang obgyn sebanyak 35 orang (pendidikan D3 kebidanan). Rumah sakit umum Sumbawa dengan motto "Bekerja Sebagai Ibadah dan Ikhlas dalam Pelayanan" memiliki visi yaitu "Terwujudnya Pelayanan Kesehatan yang Bermutu, Mandiri dan Terjangkau", dan misi sebagai berikut : (1) Meningkatkan kualitas dan kuantitas sumber daya manusia., (2) Meningkatkan kualitas dan kapasitas sarana prasarana rumah sakit, (3) Meningkatkan tata kelola keuangan melalui pemantapan implementasi PPK-BLUD. (3) Menyelenggarakan layanan kesehatan yang terjangkau., (4) Mewujudkan birokrasi yang efektif

\section{MATODE PENELITIAN}

Penelitian ini merupakan penelitian deskriptif analitik dengan pendekatan cross-sectional. Peneliti memilih desain penelitian ini untuk memperoleh data yang lebih lengkap yang dilakukan dengan cepat, sekaligus dapat mengambarkan kondisi implementasi kebijakan pelayanan kelahiran terpadu pada pasien melahirkan di rumah sakit umum daerah Sumbawa. Populasi penelitiannya yaitu seluruh pasien yang akan melahirkan di rumah sakit umum daerah Sumbawa dengan rentang waktu bulan April sampai dengan bulan Mei tahun 2020.

\section{HASIL DAN PEMBAHASAN}

Saat ini kualitas pelayanan yang diberikan oleh sektor pelayanan publik sudah menjadi menjadi bagian dari kebutuhan hidup setiap masyarakat. Setiap birokrasi publik perlu berupaya untuk memberikan kualitas pelayanan yang terbaik kepada masyarakat sebagai pengguna layanan. Pelayanan publik pemerintah dalam hal ini rumah sakit umum daerah Sumbawa saat ini dirasakan semakin perlu untuk ditingkatkan terlebih dalam era seperti ini, upaya untuk meningkatkan kualitas pelayanan publik yang lebih baik merupakan suatu keharusan yang harus segera dilakukan untuk menciptakan 
pelayanan yang lebih efisen, efektif dan sesuai dengan kebutuhan dan aspirasi masyarakat. Dari penelitian yang dilakukan, RSUD Sumbawa telah memiliki dan menggunakan SOP (Standar Operasional Prosedur) dengan baik. Kualitas SOP yang sudah ada mencakup semua kebijakan pelayanan kelahiran terpadu sehingga semua sumber daya manusia yang ada sangat paham dan menegerti akan pentingnya SOP dalam bekerja. Menurut Gasperz (2014), dalam buku manajemen kualitas dalam industry jasa mengatakan untuk memeperbaiki kinerja produksi diperlukan standar prosedur kerja (SOP).

Berdasarkan teori diatas peneliti telah melakukan koordinasi guna terbitnya SOP tersebut yang menjadi pedoman kerja dalam mengimplementasi kebijakan pelayanan kelahiran terpadu dan sudah di sesuaikan dengan teori-teori yang berlaku.

\section{Wewenang dan Tanggung Jawab RSUD Sumbawa}

Rumah sakit umum daerah Sumbawa merupakan pelaksana pelayanan publik di sektor kesehatan. Rumah sakit umum daerah Sumbawa dipimpin oleh direktur yang dalam melaksanakan tugas pokok dan fungsinya berada dibawah dan bertanggung jawab kepada bupati. Untuk kepegawaian dan bidang dipimpin oleh kepala kepegawaian dan kepala bagian tata usaha yang dalam melaksanakan tugas pokok dan fungsinya berada dibawah dan bertanggung jawab kepada direktur. Percepatan kepemilikan akta kelahiran melalui jalur kesehatan tertuang dalam peraturan bupati nomor 51 tahun 2019 sebagai perubahan atas peraturan bupati Sumbawa nomor 24 tahun 2018. mencakup tugas dan tanggung jawab rumah sakit dalam pengajuan penerbitan akta kelahiran anak, diantaranya menerima berkas permohonan dari orang tua, menerbitkan surat keterangan lahir, menyerahkan berkas permohonan kepada dinas, menerima berkas yang sudah diterbitkan selanjutnya diserahkan kepada pemohon.

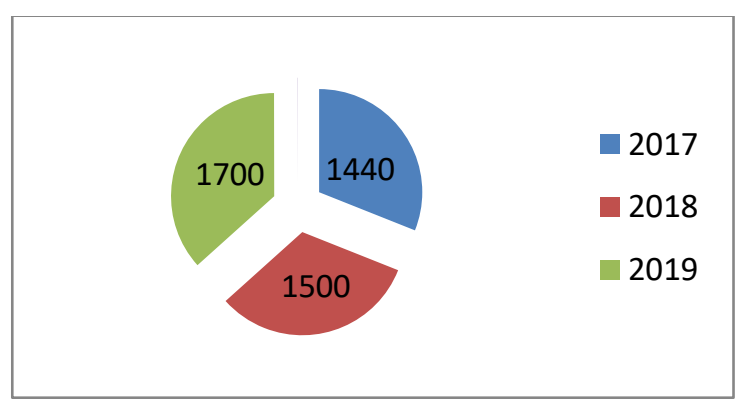

Gambar : Jumlah pasien melahirkan dalam tiga tahun terakhir

\section{Optimalisasi Sumber Daya}

Keberhasilan proses implementasi inovasi pelayanan kelahiran terpadu sangat tergantung dari kemampuan memanfaatkan sumber daya yang tersedia. Tahap - tahap tertentu dan keseluruhan proses implementasi menuntut tersedianya sumber daya manusia yang berkualitas. Sumber daya yang bisa dioptimalkan antara lain berupa sumber daya manusia dan sumber daya peralatan yang dapat digunakan untuk mendukung inovasi pelayanan kelahiran terpadu. Pembagian tugas dalam menerapkan pelayanan kelahiran terpadu sangat diperlukan untuk mendukung kelancaran proses profesionalisme dan kualitas pelayanan yang diberikan, pembagian tugas juga mengurangi resiko tingkat kesalahan dan penumpukan pekerjaan yang ada.

\section{Faktor pendukung dan penghambat}

Pemenuhan kebutuhan masyarakat oleh penyelenggara negara dengan tujuan agar dapat meningkatkan kesejahteraan msyarakat. Kebuthan dalam hal ini bukan lah kebutuhan secara individual akan tetapi berbagai kebutuhan yang sebenarnya diharapkan oleh masyarakat. Pelayanan kelahiran terpadu merupakan implementasi pelayanan public karena mencakup pelayanan untuk memenuhi kebutuhan dan hak dasar, kewajiban pemerintah dan komitmen nasional.

\section{Faktor pendukung}

Berhasil tidaknya implementasi kebijakam pelayanan kelahiran terpadu tidak hanya di sebabkan oleh faktor dari dalam organisasi atau badan penyelenggara itu sendiri. Kelompok sasaran juga menjadi faktor yang menentukan berhasil tidaknya implementasi suatu kebijakan. Dalam penelitian ini disebutkan bahwa faktor pendukung sebagian besar berasal dari internal rumah sakit umum daerah Sumbawa. (a) Kesigapan Sumber Daya Manusia, ketersedian sumber daya manusia yang handal dalam menerapkan inovasi pelayanan kelahiran terpadu menjadi faktor unggulan, sehingga pelaksanaanya dapat di selesaikan tepat waktu. Adanya pengakuan dari pasien di rumah sakit umum daerah Sumbawa yang menjadi narasumber dalam wawancara menyatakan bagusnya dan mudahnya pelayanan baru yang diterapkan. (b) Prasarana pendukung yang bagus, peralatan pendukung atau hardware yang memadai juga tersedia di rumah sakit umum daerah Sumbawa, seperti mesin foto copy yang dapat digunakan untuk melengkapi semua berkas yang menjadi persyaratan. Selain faktor sumber daya manusia faktor alat juga sangat mendukung.

\section{Faktor Penghambat}

Setiap implementasi kebijakan tentunya mengandung resiko kegagalan, Hogwood dan Gun (Rakhman, 2016) telah membagi kegagalan kebijakan (plocy failure) dalam dua kategori, yaitu 
Non-implementation dan Unsuccessful Implementation :

Suatu kebijakan tidak dilaksnakan sesuai perencanaan, karena faktor tidak ada kerjasama antar pihak yang terlibat, tidak efisien dalam bekerja, atau dalam bekerja tidak sepenuhnya menguasai perencanaan dan permasalahan yang ada (Non-implementation).

Ketika kebijakan telah dilaksanakan sesuai dengan rencana, tetapi karena faktor eksternal yang ternyata tidak menguntungkan sehingga kebijaksanaan tersebut tidak berhasil dalam mewujudkan hasil akhir atau dampak yang dikehendaki. Pelaksanaannya yang buruk (bad execution) dan kebijakan tersebut bernasib jelek (bad luck). Merupakan faktor resiko kegagalan dari suatu kebijakan (Unsuccessful Implementation)

Dalam penelitian ini juga disebutkan faktor penghambat dari implementasi pelayanan kelahiran terpadu, antara lain :

a. Kelengkapan berkas dari pasien

Salah satu dokumen persyaratan yang sering menjadi penghambat implementasi pelayanan kelahiran terpadu yaitu belum adanya nama bayi yang di lahirkan. Karena salah satu syarat menerbitkan akte kelahiran, kartu identitas anak dan kartu keluarga yakni harus sudah ada nama anaknya.

b. Kurangnya sosialisasi kepada masyarakat Masih banyak pasien yang belum mengetahui akan penerepan kebijakan pelayanan kelahiran terpadu di rumah sakit umum daerah Sumbawa. Sehingga tidak semua pasien yang melahirkan di rumah sakit umum daerah Sumbawa dapat merasakan manfaat dari inovasi pelayanan kelahiran terpadu.

\section{PENUTUP}

\section{Kesimpulan}

Kebijakan pelayanan kelahiran terpadu merupakan langkah yang maju bagi rumah sakit umum daerah Sumbawa untuk membantu masyarakat dalam menerbitkan administrasi kependudukan bagi pasien yang melahirkan di rumah sakit, Pelayanan kelahiran terpadu merupakan aplikasi dari penerapan kebijakan pelayanan publik yang baik. Adanya sarana pendukung seperti adanya SOP yang dijadikan panduan dalam penerapan inovasi pelayanan keleharinan terpadu dan tersedianya sumber daya manusia yang memahami tugas dan tanggung jawabnya merupakan faktor pendukung dari keberhasilan penerapan inovasi pelayanan kelahiran terpadu dirumah sakut umum daerah Sumbawa. Hambatan terkait implementasi pelayanan kelahiran terpadu dirumah sakit umum daerah Sumbawa berasal dari faktor eksternal.

\section{Saran}

Rumah sakit umum daerah Sumbawa harus menyusun langkah langkah strategis dalam mensosialisasikan inovasi pelayanan kelahiran terpadu agar pasien lebih dini mengetahui dan mempersiapkan semua persyaratannya. Rumah sakit umum daerah Sumbawa juga harus menyiapkan sarana ruangan khusus sebagai tempat koordinasi awal dan mendapatklan informasi yang jelas bagi pasien tentang inovasi pelayanan terpadu.

Peneliti juga berharap akan ada penelitan selanjutnya sebagai penegembangan dari penelitian ini sehingga diharapkan kedepannya hal - hal yang dapat menghambat sebuah kebijakan bisa diminimalisir, karena kepuasan masyarakat atau pasien merupakan sesuatu yang bersifat sangat mutlak

\section{REFERENSI}

Ariyadi, B. (2016). Model aplikasi sistem pelayanan terpadu pada kantor kelurahan. ISSN 20893787,895

Alkano. (2016). Inovasi Kualitas Pelayanan Kesehatan Instalasi Gawat Darurat Modern. Jakarta. Rineka Cipta

Barata, (2015). Dasar-dasar Pelayanan Prima. Jakarta. PT. Elex Media Komputindo.

Dwiyanto. (2015). Reformasi Birokrasi Publik di Indonesi, Galang Printika, Yogyakarta.

Gunawan, E. (2014). Pembuatan sistem informasi pelayanan masyarakat terpadu, jurnal ilmiah mahasiswa universitas Surabaya vol 2 no. 2

Gasperz, (2014). Manajemen Kualitas Dalam Industrian Jasa, Jakarta. PT. Gramedia Pusaka.

Kementerian Pendayagunaan Aparatur Negar RI. (2004). Pedoman Pelayanan Satu Pintu.: Jakarta.

Patmasari, R. (2016). Analisis Inovasi Pelayanan Aplikasi Pendafataran Tanpa antrean dengan Sistem Online diRumah Sakit. http:/e/journal3.undip.ac.id.exe. diakses tanggal 23 januari 2020. Jam 19.30

Peraturan Bupati, (2018). Percepatan Kepemilikan Akta Kelahiran Melalui Jalur Pendidikan, Kesehatan, Sistem Layanan Rujukan Terpadu dan Desa /Kelurahan. Nomor 24

, (2019). Perubahan Atas Peraturan Bupati Sumbawa Nomor 24 Tahun 2018 Tentang Percepatan Kepemilikan Akta Kelahiran Melalui Jalur Pendidikan, Kesehatan, Sistem Layanan Rujukan Terpadu dan Drsa/Kelurahan. Nomor 51 
Rakhman, D. (2016). Implementasi kebijakan pelayanan Administrasi kependudukan terpadu. Jurnal administrasi publik, 962 